\title{
Adoption Model of Falcataria-Based Farm Forestry: A Duration Analysis Approach
}

\author{
Evi Irawan \\ Balai Penelitian dan Pengembangan Teknologi Pengelolaan DAS, Jl. A. Yani, Pabelan, \\ P.O. Box 295, Surakarta 57102 \\ Correspondence E-mail: evirawan17@gmail.com
}

Received: March 2016; Accepted: June 2016

\begin{abstract}
Farm forestry is a form of farming systems that provides economic and environmental benefits. The salient feature of this system is the incorporation of commercial perennial plants, in particular forest trees, into farming systems and can take many forms, including timber belts, alleys and widespread tree plantings. While the system in some locations has been well adopted, the farmers or land users in other location are reluctant to adopt them, although the traits of farmers and farm land in both locations are similar. Recent adoption studies of farm forestry were in general applied static approaches which overlooked the dynamic aspect of adoption decisions. Meanwhile, information about dynamics of adoption decision making is necessity in designing extension policies as well as reengineering innovations to align with socio-economic conditions of the farmers. To close this gap, this paper is to examine factors affecting the speed of farm forestry adoption among small-holders using duration analysis. Results show that the speed of adoption were influenced by some variables included age of household head, level of education of household head, off-farm employment and output price. It is found that farmers with older age tend to adopt faster than the younger ones. The speed of adoption were also affected by whether the farmers engaged in off-farm employment or being a member of farmers group. The policy implications of this research are that government should design policies that promote farmers' participation in off-farm income activities and strengthening farmer groups in addition to extension services and timber markets.
\end{abstract}

Keywords: Adoption, duration analysis, farm forestry, Falcataria moluccana, Cox proportional hazard JEL Classification: Q12

\section{Introduction}

Falcataria-based farm forestry is an example of innovative farming system practice designed to enhance productivity of marginal land that in the same time contributes to climate change mitigation through enhanced carbon sequestration. This practice has been thought of as an integral part in sustainable rural development in Indonesia, particularly villages located in marginal areas (van Der Poel \& van Dijk, 1986). Some evidences from several places in Java indicated the adoption of farm forestry has brought financial benefits to the farmers and environmental benefits to society. Farm forestry in Java was estimated to store at least 40 million ton C (Balai Pemantapan Kawasan Hutan Wilayah XI Jawa Madura \& Multistakeholder Forestry Programme, 2009).

The promotion of farm forestry to small-holders in Indonesia has been carrying out since 1970s through a number of national movements of treeplanting. The programs have found their momentum when the issues of climate change increasingly prevailing. Furthermore, Indonesia is 


\section{Jurnal Ekonomi Pembangunan, 17 (1), Juni 2016, 28-36}

one of the world's largest greenhouse gas emitters, with $80 \%$ of its emissions originating largely from agriculture, forestry and other land use (Yumamoto \& Takeuchi, 2012). The programs were also supported by huge amount of state budget. In 1970-1980s, Indonesian government allocated in an average amount of US\$ $100-125$ million annually for at least 250 re-greening projects (Mangundikoro, 1986). In 2003-2009, the government has spent at least US\$ 300 million annually to run national movement for land and forest rehabilitation. Nonetheless, this huge amount of state expenditure seems likely to be followed only by low level of adoption of farm forestry (Irawan, 2011). The establishments of farm forestry on private lands in Indonesia are widely varied between one to other locations. In some locations the farm forestry systems have been well-taken up, while in many other locations the farmers or land users are reluctant to adopt them, although the traits of farmers and ecological circumstances in both locations are likely similar (Irawan, 2011).

Studies of agroforestry adoption, including farm forestry, have been conducted for many years in many areas. A number of scholars (e.g. Pattayanak, Mercer, Sills, \& Yang, 2003; Mercer, 2004) have reviewed comprehensively factors affecting decision to adopt agroforestry innovations. Most studies of adoption of agroforestry innovations applied dichotomous choice model and thereby they cannot properly explain the individual timing of an adoption decision, meaning the time a farmer takes until he/she adopts an innovation (e.g. Boulay, Tacconi, \& Kanowski, 2012; Gyau, Chiatoh, Franzel, Asaah, \& Donovan, 2012; Kakuru, Doreen, \& Wilson, 2014; Sabastian, Kanowski, Race, Williams, \& Roshetko, 2014). This paper examines the information gap between static and dynamic nature of adoption studies by providing information on duration analysis of adoption of Falcataria-based farm forestry. The main objective is to seek determinant factors contributing on the speed of adoption of Falcataria-based farm forestry.

\section{Research Location and Data Collection}

Data used in this study were derived from a cross-sectional survey carried out in Tempurejo, a village located in Wonosobo Regency in Central Java Province, Indonesia. Research location was selected purposively by considering several factors as follows: (1) the village was one of the main producers of Falcataria wood (Falcataria moluccana) in Java; (2) it lies on up-stream area of Medono sub-watershed and therefore, the sustainability of forested areas in this village has pivotal role in watershed protection, especially for the downstream areas that includes Purworejo and Kebumen regency, and (3) the village is part of ring two of greenbelt zone of Wadas Lintang reservoir that is main supplier of irrigation water for agricultural production, especially rice farming, in downstream areas of Medono sub-watershed (Figure 1).

Data were collected through face-to-face interviews using structured questionnaire as instrument. For this research, we selected randomly 117 respondents from a sampling frame of \pm 700 farmers. The questionnaire was designed to collect information about general socio-economic characteristics including respondent's age (AGET), formal education (EDUC), off-farm employment (OFFE), membership to farmers' group (FORG), family size (HHSZ), size of farmland (FARM), and relative prices of Falcataria log to coffee (Coffea robusta) bean per kilograms at the farm gate (PRIC). In addition, information of the length of time a farmer took from the date he first introduced about farm forestry to the date he adopted was collected. This variable was measured as suggested by Burton, Rigby and Young (2003) as the date at which the innovation was first made available or the date at which the respondent started farming, whichever is the latest, till the time the farmer adopted the technology. Falcataria-based farm forestry is a relatively new technology. 


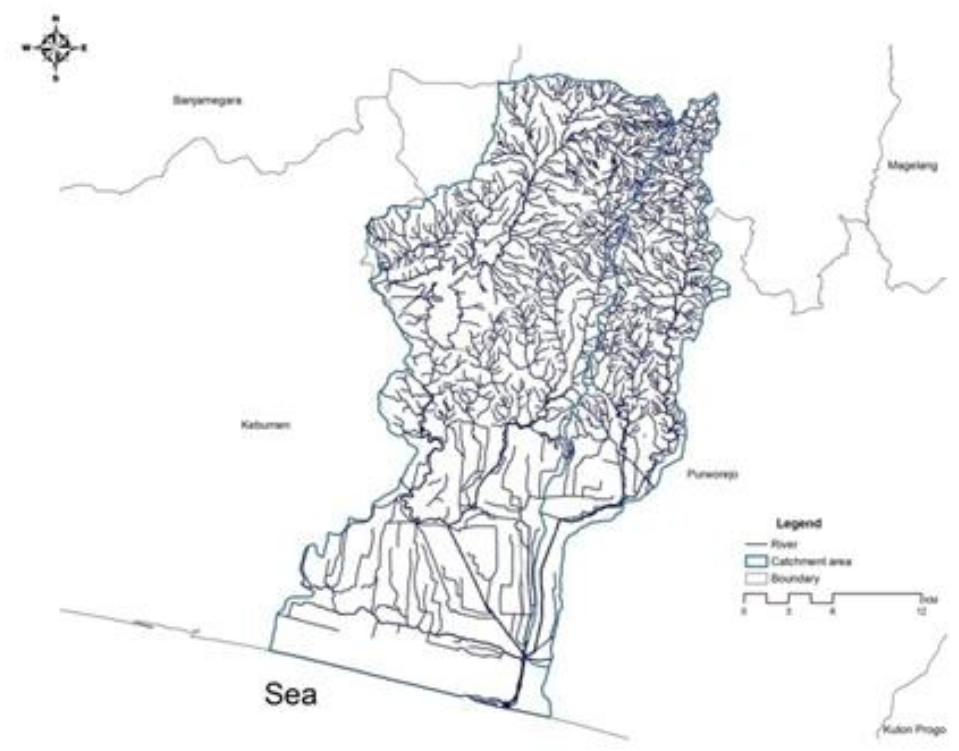

Figure 1.Medono Sub-Watershed area

This farming system was firstly introduced in Indonesia, especially in Java in 1989 through 'Sengonisasi' Program. Based on this information we selected the first entry date was the year the farmer first learnt about the technology with 1989 as the earliest year of first adopter.

\section{Empirical Model Specification and Data Analysis}

Data analysis was performed using duration analysis approach; a statistical method which sometimes is so-called as survival analysis or event history analysis. The selection of duration analysis approach was based on consideration of its ability to model time to an event. Three equivalent functions are commonly used to describe the distribution of duration data includes: survival function, hazard function, and cumulative hazard function. Suppose for a given farmer, define $T$ as "failure" time, at which a farmer makes a transition from non-adoption to adoption. The probability that a farmer adopts Falcataria-based farm forestry at time $t$ is defined by a conditional distribution function $F(t)$ as:

$$
F(t)=\operatorname{Pr}(T \leq t)
$$

$T$ is non-negative continuous random variable representing the length of time a farmer stays in the non-adoption state. Variable $t$ is the actual time a farmer takes from being a non-adopter to being an adopter. Nevertheless, not all farmers had adopted Falcataria-based farm forestry system at time $t$. Therefore, the probability of not adopting at time $t$ is defined as a survival function $(S(t))$, which is defined as:

$$
S(t)=1-F(t)=\operatorname{Pr}(T>t)
$$

In order to explore the relationship between explanatory variables to timing of adoption, it is necessary to specify hazard function $h(t)$, which is defined as the probability that farmer $i$ adopts Falcataria-based farm forestry at time $t+\Delta t$, conditional on the fact that the adoption has not yet occurred by $t$ and $\Delta t$ is short interval of time. Hazard rate is formally given as:

$$
\begin{aligned}
h(t) & =\lim _{\Delta t \rightarrow 0} \frac{\operatorname{Pr}(t \leq T<t+\Delta t \mid T \geq t)}{\Delta t} \\
& =\lim _{\Delta t \rightarrow 0} \frac{F(t+\Delta t)-F(t)}{\Delta S(t)}=\frac{f(t)}{S(t)}
\end{aligned}
$$


To account for the influence of the allegedly determinant factors, the hazard function was redefined as follows (Box-Steffensmeier \& Jones, 2004; Madlener \& Schmid, 2003):

$$
h(t \mid x)=h_{0}(t) g(x, \beta)
$$

Where $h_{\mathrm{o}}(t)$ is the baseline hazard, that is the hazard rate that is solely a function of time and is independent of the covariates, $x, \beta$ is a vector of parameters to be estimated and $g$ is a nonnegative function that acts multiplicatively on the baseline hazard. Following previous empirical adoption studies (Abdulai \& Huffman, 2005; Burton, Rigby, \& Young, 2003; Dadi, Burton, \& Ozanne, 2004), $g(\bullet)$ is commonly expressed as:

$$
g(x, \beta)=\exp \left(\beta^{\prime} x\right)
$$

Following Burton et al. (2003), the baseline hazard and the effect of covariates on the hazard function was estimated using proportional-hazards rate.

This present study applied duration analysis method, specifically Cox proportional-hazard regression model (Cox model), to estimate the influence of allegedly determinant factors on the time lag preceding adoption of Falcataria-based farm forestry. The Cox model does not assume a particular parametric form the baseline hazard. In the model, is assumed to be unknown and is left un-parameterized, thus minimizing the risk of functional misspecification and hence biased coefficient estimates. Cox regression models do not have an intercept term (Box-Steffensmeier and Jones 2004). This study uses empirical Cox model as follows:

Model 1:

$$
\operatorname{ADOPT}(i, t)=\exp \left(\begin{array}{l}
\beta_{1} A G E T_{i, t}+\beta_{2} E D U C_{i, t}+\beta_{3} O F F E+\beta_{4} P R I C_{i, t} \\
+\beta_{5} F O R G_{i, t}+\beta_{6} F A R M_{i, t}+\beta_{7} H H S Z_{i, t}
\end{array}\right)
$$

Model 2:

$$
\operatorname{ADOPT}(i, t)=\exp \left(\begin{array}{l}
\beta_{1} A G E T_{i, t}+\beta_{2} E D U C+\beta_{3} O F F E_{i, t}+\beta_{4}(E D U C x O F F E)_{i, t} \\
+\beta_{5} F O R G_{i, t}+\beta_{6} F A R M_{i, t}+\beta_{7} H H S Z_{i, t}+\beta_{8} P R I C_{i, t}
\end{array}\right)
$$

Description of all variables is provided in Table 1. Human capital is represented by age (AGET) and education (EDUC) which reflects the social aspects of the farmer and their ability to obtain and evaluate information about innovation. Offfarm employment (OFFE) and household size (HHSZ) is linked to supply of farm labor since farm forestry is usually less labor intensive than that of staple crop and horticultural production (Irawan 2012). Farm land size (FARM) isused as indicators household's wealth. Farmers' group membership (FORG) represents the effects of information of an innovation a farmer derives from group contact. Relative price of Falcataria log to coffee (PRIC) is linked to the incentives of adopting Falcatariabased farm forestry (Burton et al., 2003). In the Model 2 (Equation (7)), we introduced the interaction effect of variable FORG and OFFE on the duration of adoption in order to examine whether the farmer who has off-farm employment and a member of farmers' group adopt more faster than those who do not have.

The method of estimation used to obtain the coefficients for Equation (6) is maximum likelihood (ML) estimation (Box-Steffensmeier and Jones 2004). A multi-collinearity test was done using variance inflation factor (VIF). All of statistical analyzes was done using STATA 13. 
Available online at http://journals.ums.ac.id

Jurnal Ekonomi Pembangunan, 17 (1), Juni 2016, 28-36

Table 1. Description of the variable used in the duration of statistical model analysis

\begin{tabular}{|c|c|c|c|c|c|}
\hline Variable & Description of the variable & Mean & $\begin{array}{l}\text { Std. } \\
\text { Dev. }\end{array}$ & Min & $\operatorname{Max}$ \\
\hline \multicolumn{6}{|l|}{ Dependent variable } \\
\hline ADOPT & $\begin{array}{l}\text { Number of years from the date of first } \\
\text { hearing to the date of adoption. (years) }\end{array}$ & 11.026 & 5.149 & 1 & 19 \\
\hline \multicolumn{6}{|l|}{ Explanatory variables } \\
\hline Age (AGET) & $\begin{array}{l}\text { Age of farmer when he adopted farm } \\
\text { forestry. (years) }\end{array}$ & 31.453 & 8.107 & 15 & 53 \\
\hline Education (EDUC) & Years of formal education. (years) & 6.231 & 2.339 & 0 & 12 \\
\hline $\begin{array}{l}\text { Off-farm employment } \\
\text { (OFFE) }\end{array}$ & $\begin{array}{l}\text { Farmer has off-farm employment. } 1= \\
\text { Yes, } 0=\text { No }\end{array}$ & 0.479 & - & 0 & 1 \\
\hline $\begin{array}{l}\text { Member of farmers' } \\
\text { group (FORG) }\end{array}$ & $\begin{array}{l}\text { Membership to farmers' group. } 1=\text { Yes, } \\
0=\text { No }\end{array}$ & 0.393 & - & 0 & 1 \\
\hline Farm size (FARM) & $\begin{array}{l}\text { Size of farmland owned by farm } \\
\text { household at the time of adoption. (ha) }\end{array}$ & 0.807 & 0.675 & 0.018 & 3.023 \\
\hline Price (PRIC) & $\begin{array}{l}\text { Relative price of Falcataria logto price } \\
\text { of coffe bean } / \mathrm{kg} \text { at the time of adoption. }\end{array}$ & 11.054 & 2.620 & 7.619 & 20 \\
\hline $\begin{array}{l}\text { Number of adults } \\
\text { (HHSZ) }\end{array}$ & $\begin{array}{l}\text { Number of adults in household with the } \\
\text { age more than } 15 \text { years old. (people) }\end{array}$ & 3.504 & 1.119 & 1 & 8 \\
\hline
\end{tabular}

\section{Results and Discussion}

Falcataria-based farm forestry is a relatively new innovation introduced to smallholders in Java through re-greening program, which is so-called GerakanSengonisasi (Falcataria planting movement). Re-greening program itself has been established in Indonesia since 1976 with main objective was to rehabilitate critical land areas outside state-declared forest areas, particularly upland farm areas(Nawir et al. 2007). Before Sengonisasi, the government introduced a number of re-greening programs using multipurpose fastgrowing legume trees, such as Sesbania grandiflora and Leucaenasp. The promotion to farmers was undertaken through mass campaign so-called Gerakan Nasional Penanaman Turi/Lamtoro (nationnal movement of Sesbania or Leucaena planting). This massive planting was fully supported by government by providing free seed/seedlings, extension services, planting wage etc. However, the massive planting of Leucaena was induced the infestation of Kutuloncat insect (Heteropsylacubana) in the late of $1980 \mathrm{~s}$ and destroyed almost all of Leucaena trees, especially in Java. To secure re-greening program, the government replaced Leucaena with Falcataria as another prospective multipurpose fast-growing tree in 1989.

The same as in other areas in Indonesia, Falcataria-based farm forestry was introduced in Wonosobo regency soon after the launching of Gerakan Sengonisasi by Ministry of Forestry. At that time, the government provided free seedlings to farmers, especially smallholders. In addition, they also got technical assistance from forestry extension workers. Nevertheless, not all potential farmers were willing to adopt the Falcataria tree at that time. Some even threw away the seedlings freely provided by extension workers. Figure 2illustrates a graphical presentation of the number of farmers by year of adoption of Falcataria-based farm forestry. From 1990 to 2008, the cumulative number of adopters increaseslinearly with rate $5.77 \%$ per annum on average.

Kaplan-Meier estimates of the survival function for adoption are plotted in Figure 3. The horizontal axis shows the number of years that elapsed from the date of the introduction of Falcataria tree to the year of first adoption. 


\section{Jurnal Ekonomi Pembangunan, 17 (1), Juni 2016, 28-36}

The function is falling gradually depicting slow adoption rate. This trend can be attributed to the nature of tree production that needs longer gestation period than that of staple or vegetable crops. Since most farmers are not a risk taker, this implies that to reach final decision whether to adopt the innovation, they must spend some time to have real example of Falcataria production. Overall, the minimum recorded time to adoption from the time of introduction of Falcataria-based farm forestry was 1 year, and a maximum of 19 years, with a mean of 11.026 years.

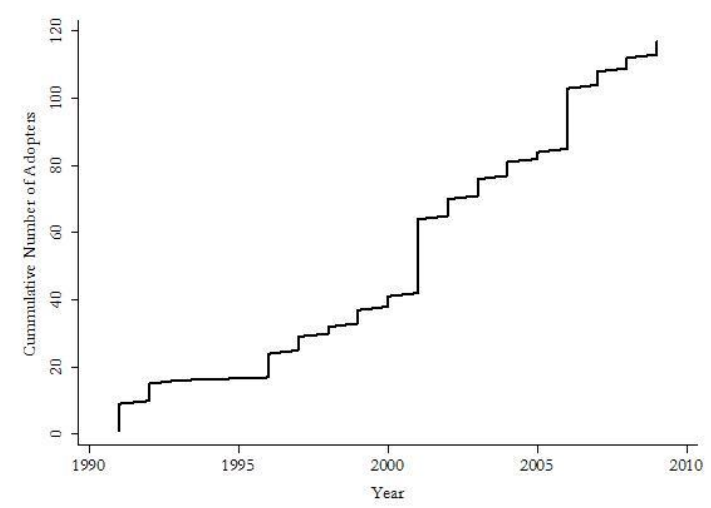

Figure 2. Adoption of Falcataria-based farm forestry in sample, 1990-2008

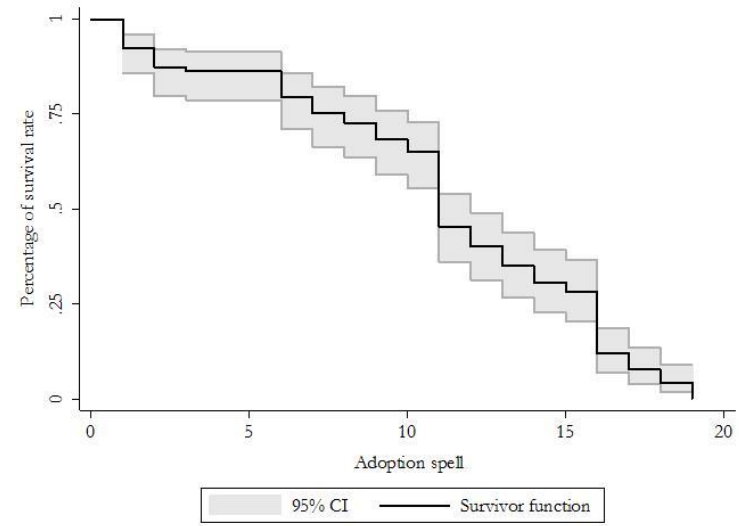

Figure 3. Kaplan-Meier survival estimate of adoption of Falcataria-based farm forestry

Turning to Cox model estimation, we first examined the existence of multicollinearity among variables included in the model using VIF. The results indicated that all variables fitted in the models had a VIF less than 10 which signify inexistence of multicollinearity (Greene 2002; Maddala 1993)

Table 2 displays the estimation results of the duration model. The measure of effect is represented by a hazard ratio. A ratio bigger (smaller) than one speeds up (slows down) the adoption process; subtracting 1 from the hazard ratio results in the marginal effect of the variable on the hazard rate of adoption.

Table 2.Cox proportional-hazard estimation of the coefficient and hazard rate of adoption

\begin{tabular}{|c|c|c|c|c|c|c|}
\hline \multirow[b]{2}{*}{ Variables } & \multicolumn{3}{|c|}{ Model 1} & \multicolumn{3}{|c|}{ Model 2} \\
\hline & Hazard & Ratio & $\begin{array}{c}\text { Standard } \\
\text { Errors (Robust) }\end{array}$ & Hazard & Ratio & $\begin{array}{c}\text { Standard } \\
\text { Errors (Robust) }\end{array}$ \\
\hline 1. AGET & 1.044 & $* * * *$ & 0.013 & 1.042 & $* * *$ & 0.013 \\
\hline 2. EDUC & 1.325 & $* * *$ & 0.092 & 1.117 & $* *$ & 0.064 \\
\hline 3. OFFE & 2.920 & $* * *$ & 0.634 & 0.215 & $* *$ & 0.147 \\
\hline 4. EDUC $\times$ OFFE & - & & & 1.566 & $* * *$ & 0.170 \\
\hline 5. FORG & 3.570 & $* * *$ & 0.871 & 3.153 & $* * *$ & 0.762 \\
\hline 6. HHSZ & 0.952 & & 0.089 & 0.974 & & 0.085 \\
\hline 7. FARM & 1.297 & $* *$ & 0.146 & 1.300 & $* *$ & 0.153 \\
\hline 8. PRIC & 1.272 & $* * *$ & 0.069 & 1.205 & $* * *$ & 0.079 \\
\hline Log-likelihood & -398.183 & & & -393.601 & & \\
\hline Wald chi ${ }^{2}$ & 192.84 & $* * *$ & & 225.83 & $* * *$ & \\
\hline
\end{tabular}

Notes:*, ${ }^{* *},{ }^{* * *}$ significant at the $10 \%, 5 \%$, and $1 \%$ level, respectively

The estimates of both models (Model 1 and Model significantly, except the size of farm household 2) show that all of variables speed up adoption (HHSZ). These results in part are 


\section{Jurnal Ekonomi Pembangunan, 17 (1), Juni 2016, 28-36}

consistent with findings from previous duration analyses with respect to other agricultural innovations (Abdulai and Huffman 2005; Burton et al. 2003; Dadi et al. 2004; Matuschke and Qaim 2008). Overall, variables in both models have similar effects on the duration of adoption.

Age of farmer (AGET) in Model 1 and 2 are statistically significant at $1 \%$ level and have hazard ratio more than 1 , signaling that elderly people are likely to take shorter time to adopt Falcataria-based farm forestry. One year of additional age increases the hazard rate of adoption by about $4 \%$. With advance in age, the farmer is likely to participate in less strenuous manual agricultural activities, such as farm forestry. This finding is consistent with Abdulai and Huffman (2005). They argued that elderly farmers may have accumulated capital and may be preferred by credit institutions, both of which may make them more prepared to adopt technology faster than younger ones.

Education variable (EDUC) has a positive effect suggesting an increase by one year increases the adoption hazard by $11-30 \%$. This result supports the human capital theory which states that innovative ability is closely related to education level (Becker 1964; Becker 1985). More educated farmers are typically assumed to be better able to process information and search for appropriate technologies to alleviate their production constraints. The belief is that higher level of education gives farmers the ability to perceive, interpret and respond to new information much faster than their counterparts. This finding also consistent with the empirical studies of adoption of agricultural innovation using duration analysis (Alcon et al. 2011; Burton et al. 2003; Dadi et al. 2004; Matuschke and Qaim 2008)

As expected, off-farm employment (OFFE) and membership to farmers' group (FORG) have statistically significant speed up adoption of Falcataria-based farm forestry. Closer look at the magnitude of hazard ratio in Model 1 and Model 2, it can be recognized that both variables have much higher hazard ratio than that of other variables. These imply that the farmers' group has important role in spreading information of farm forestry since extension service agents often use a farmers' group as a focal point. We can expect participation through groups and the support of a community network to mitigate some of the uncertainties associated with new technology. The groups and networks could also provide extension and training. The significance of off-farm employment on the speed of adoption can be attributed to the nature of farm forestry system, which are less labor-intensive and long gestation period. Thus, the farmers having off-farm employment are less dependence on farm income than those are not having off-farm employment.

In addition, Model 2 includes an interaction term which is generated from the multiplication of variable OFFE and EDUC. The reason to include this interaction term is that the farmers having offfarm employment are most likely those who are more educated as indicated in the previous empirical studies of adoption of on-farm tree planting (e.g. Boulay et al. 2012; Gyau et al. 2012; Kakuru et al. 2014). The estimation result of Model 2 reveals that hazard ratio of interaction term (EDUC x OFFE) has a magnitude more than 1 and statistically significant at $1 \%$ level, indicating that the effect of EDUC subject to the presence of OFFE speed-up the adoption of Falcataria-based farm forestry.

The same as many previous empirical adoption studies of tree planting(e.g. Boulay et al. 2012; Gyau et al. 2012; Kakuru et al. 2014), the resource endowment, that is farm size (FARM), has significant influence on the speed of adoption. According to theory of adoption of innovation (e.g. Feder et al. 1985; Feder and Umali 1993; Rogers 2010) and empirical literature (e.g. Boulay et al. 2012; Hayami 1981; Sabastian et al. 2014) its early adopters tend to be the better-off farmers who are better situated to take advantage of new innovations with uncertain prospects. These households are more 


\section{Jurnal Ekonomi Pembangunan, 17 (1), Juni 2016, 28-36}

likely to havethe necessary 'risk capital', such as land, to facilitate risky investment in unproven technologies.

Agricultural and tree-product prices arewellknownfactors influencing landuse decisions (Godoy, 1992; Pattayanak, Mercer, Sills, \& Yang, 2003; Shively, 1999). The results of Cox model estimation (Table 2) indicate that relative prices of Falcataria increase the speed of adoption. An increase in price byone unitincreases the adoption hazard by more than $26 \%$. This result implicitly implies that the farmers require market incentive which is reflected from the prices for the tree to compensate long waiting time to adopt Falcataria-based farm forestry.

\section{CONCLUSION}

This study has demonstrated that duration analysis conveys information on the timing of the adoption decision, which cannot be provided by static discrete choice models. The study reveals that determinant factors that influence the speed of adoption were age of farmer, education, off-farm employment, farm size, membership to farmers' group and price. In addition, it is also found that the influence of off-farm employment and membership to farmers' group to the speed of adoption are much higher than any other factors. Furthermore, farmers who are well educated and have off-farm employment are among the earlier adopters. Policy insights derived in the context of this study suggest that speeding up Falcatariabased farm forestry requires policies that promote farmers' participation in off-farm income activities and timber markets in addition to access to extension services.

\section{References}

Abdulai A, Huffman WE (2005) The diffusion of new agricultural technologies: the case of crossbred-cow technology in Tanzania American Journal of Agricultural Economics 87:645-659
Alcon F, de Miguel MD, Burton M (2011) Duration analysis of adoption of drip irrigation technology in southeastern Spain Technological Forecasting and Social Change 78:991-1001

Balai Pemantapan Kawasan Hutan Wilayah XI Jawa Madura, Multistakeholder Forestry Programme (2009) Strategi pengembangan, pengelolaan dan arahan kebijakan: Hutan rakyat di pulau Jawa. Departemen Kehutanan,

Becker G (1964) Human Capital. University of Chicago Press, Chicago, IL

Becker GS (1985) Human capital, effort, and the sexual division of labor Journal of Labor Economics 3:S33 -S58

Boulay A, Tacconi L, Kanowski P (2012) Drivers of adoption of eucalypt tree farming by smallholders in Thailand Agroforestry System 84:179-189

Box-Steffensmeier JM, Jones BS (2004) Event History Modelling: A Guide for Social Scientists. 1st edn. Cmabridge University Press, Cambridge, UK

Burton M, Rigby D, Young T (2003) Modelling the adoption of organic horticultural technology in the UK using Duration Analysis The Australian Journal of Agricultural and Resource Economics 47:29-54

Dadi L, Burton M, Ozanne A (2004) Duration analysis of technology adoption in Ethiopian agriculture Journal of Agricultural Economics 55:613-631

Feder G, Just RE, Zilberman D (1985) Adoption of agricultural innovations in developing countries: A survey Economic development and cultural change:255-298

Feder G, Umali DL (1993) The adoption of agricultural innovations: a review Technological forecasting and social change 43:215-239 


\section{Jurnal Ekonomi Pembangunan, 17 (1), Juni 2016, 28-36}

Greene WH (2002) Econometric analysis. 5 edn. Prentice Hall, Upper Saddle River, NJ

Gyau A, Chiatoh M, Franzel S, Asaah E, Donovan J (2012) Determinants of farmers' tree planting behaviour in the north west region of Cameroon: the case of Prunus africana International Forestry Review 14:265-274

Hayami Y (1981) Induced innovation, green revolution, and income distribution: comment Economic Development and Cultural Change:169-176

Irawan E (2011) Nilai Ekonomi Hutan Rakyat untuk Penyerapan Emisi Karbon Jurnal Penelitian Sosial dan Ekonomi Kehutanan 8:54-70

Irawan E (2012) The effect of labor organization on integrated pest management (IPM) adoption: Empirical study of Durian and Tangerine Production in Thailand. Institutional Change in Agriculture and Natural Resources. Shaker Verlag, Aachen, Germany

Kakuru O, Doreen M, Wilson M (2014) Adoption of On-Farm Tree Planting in Kibaale District, Western Uganda Journal of Sustainable Forestry 33:87-98

Maddala GS (1993) Limited-dependent and Qualitative Variables in Econometrics. Cambridge University Press, Cambridge, UK

Madlener R, Schmid C (2003) Adoption and diffusion of decentralised energy conversion technologies: the success of engine cogeneration in Germany Energy and Environment 14:627-662

Mangundikoro A (1986) Watershed Management in Indonesia with Special Reference to Institution Strengthening and its
Framework Improvement. In: Brooks KN (ed) Strategies, approaches and systems in integrated watershed management (FAO Conservation Guide 14). Food and Agriculture Organization, Rome, Italy, $\mathrm{p}$ 237

Matuschke I, Qaim M (2008) Seed market privatisation and farmers' access to crop technologies: The case of hybrid pearl millet adoption in India Journal of Agricultural Economics 59:498-515

Mercer DE (2004) Adoption of agroforestry innovations in the tropics: A review Agroforestry System 11:311-328

Nawir AA, Murniati, Rumboko L (2007) Forest rehabilitation in Indonesia: Where to after three decades? Center for International Forestry Research, Bogor

Pattayanak SK, Mercer DE, Sills E, Yang J-C (2003) Taking stock of agroforestry adoption studies Agroforestry System 57:173-186

Rogers EM (2010) Diffusion of innovations. Simon and Schuster,

Sabastian G, Kanowski P, Race D, Williams E, Roshetko JM (2014) Household and farm attributes affecting adoption of smallholder timber management practices by tree growers in Gunungkidul region, Indonesia Agroforestry systems 88:257-268

van Der Poel P, van Dijk H (1986) Household economy and tree growing in upland Central Java Agroforestry System 5:169184

Yumamoto Y, Takeuchi K (2012) Estimating the break-even price for forest protection in Central Kalimantan Environmental Economics and Policy Studies 14:289-301 